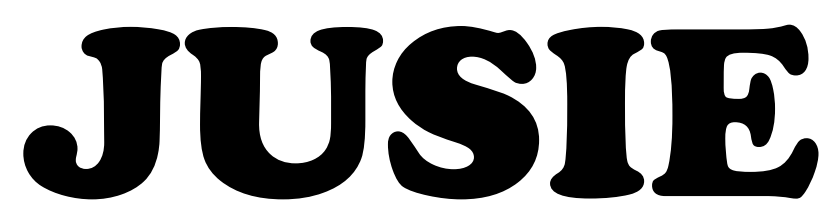

(Jurnal Sosial dan Ilmu Ekonomi)

Volume IV, Nomor 02, November 2019 - April 2020

Pengaruh Knowledge, Skill dan Ability Pimpinan terhadap Kinerja IKM di Kabupaten Pesisir Selatan

Penulis $\quad$ : Rahmad, Sabri dan Nasfi

Sumber : Jurnal Sosial dan Ilmu Ekonomi, Volume IV, Nomor 02, November 2019 April 2020

Diterbitkan oleh: Jurusan PIPS FKIP UMMY Solok

Copyright @ 2019, Jurnal Sosial dan Ilmu Ekonomi, Volume IV, Nomor 02, November 2019-April 2020| 108 
Jurnal Sosial dan Ilmu Ekonomi

Volume IV, Nomor 02, November 2019 - April 2020, p. 108 - 117

ISSN : 2654-6302 (Print)

ISSN : 2503-1503 (Online)

https://ojs.fkipummy.ac.id/index.php/jusie
JUSIE

(Jurnal Sosial dan Ilmu Ekonomi)

\title{
Pengaruh Knowledge, Skill dan Ability Pimpinan terhadap Kinerja IKM di Kabupaten Pesisir Selatan
}

\author{
Rahmad $^{1}$, Sabri $^{2}$ Nasfi $^{3}$ \\ 1,2 Sekolah Tinggi Ilmu Ekonomi Haji Agus Salim Bukittinggi \\ ${ }^{3}$ STES Manna Wa Salwa, Padang Panjang \\ Email : rafa.dafa2013@gmail.com \\ Email : sabribgk@gmail.com \\ Email:nasfi.anwar@gmail.com
}

\begin{abstract}
The object of this study is IKM Selatan Pesisir Regency, to examine the effect of Knowledge, Skill and Ability of Leaders on Performance in IKM South Pesisir Regency. The purpose of this study is to determine how the model can provide a more precise description of the causality relationship between Knowledge, Skill, Leadership Ability and Performance. The population in this study is the total number of employees in the South Coastal District IKM with a total of 1,656 employees. With a sample of 100 people taken from a number of business units engaged in manufacturing such as the production of handicrafts, food, bags, shoes, crackers, garments and so on at IKM South Coastal District. Analysis of the research data used is the structural equation model with the SPSS application program to test 4 (two) hypotheses that have been developed, the hypothesized relationship is a causal relationship. And the results of the hypothesis show that 4 (two) proposed hypotheses are accepted. The significance value of the Knowledge variable $\left(X_{1}\right)$ is 0.031 , the significance value of the Skill variable $\left(X_{2}\right)$ is 0.028 and the significance value of the Ability variable $\left(X_{3}\right)$ is 0.046 , it is evident that if the significance value (sig) or probAbility value (probAbility) smaller than the significant level used $(=0.05)$, it can be concluded that there is a significant influence of the variables Knowledge $\left(X_{1}\right)$, Skill $\left(X_{2}\right)$ and Ability $\left(X_{3}\right)$ on Performance in IKM South Coastal District.
\end{abstract}

Keywords: Performance, Knowledge, Skill, Ability

\begin{abstract}
ABSTRAK
Obyek Penelitian ini adalah IKM Kabupaten Pesisir selatan, untuk menguji pengaruh Knowledge, Skill dan Ability Pimpinan terhadap Kinerja di IKM Kabupaten Pesisir Selatan. Adapun tujuan penelitian ini untuk menentukan bagaimana model tersebut dapat memberikan gambaran lebih tepat hubungan kausalitas antara Knowledge, Skill, Ability Pimpinan dan Kinerja. Populasi dalam penelitian ini adalah jumlah keseluruhan karyawan pada IKM Kabupaten Pesisir Selatan dengan jumlah karyawannya sebanyak 1.656 orang. Dengan sampel sebanyak 100 orang diambil dari sejumlah unit Usaha yang bergerak dibidang Manufaktur seperti produksi kerajinan, makanan, tas, sepatu, kerupuk, garmen dan sebagainya di IKM Kabupaten Pesisir Selatan. Analisis data penelitian yang dipergunakan adalah model persamaan struktural dengan program aplikasi SPSS untuk menguji 4 (dua) hipotesis yang telah dikembangkan, hubungan yang telah dihipotesiskan merupakan hubungan kausal. Dan dari hasil hipotesis menunjukan bahwa 4 (dua) hipotesis yang diajukan diterima. Nilai signifikansi dari variabel Knowledge $\left(X_{1}\right)$ adalah sebesar 0,031, Nilai signifikansi dari variabel Skill $\left(X_{2}\right)$ adalah sebesar 0,028 dan Nilai signifikansi dari variabel Ability
\end{abstract}


$\left(X_{3}\right)$ adalah sebesar 0,046, maka terbukti Jika nilai signifikansi (sig) atau nilai probabilitas (probAbility) lebih kecil dari tingkat signifikan yang digunakan $(\alpha=0,05)$, maka dapat disimpulkan bahwa terdapat pengaruh yang signifikan dari variabel Knowledge $\left(X_{1}\right)$, Skill $\left(X_{2}\right)$ dan Ability $\left(X_{3}\right)$ terhadap Kinerja di IKM Kabupaten Pesisir Selatan.

\section{Kata kunci : Kinerja, Knowledge (Pengetahuan), Skill (Keterampilan), Ability (Kemampuan)}

\section{PENDAHULUAN}

Manusia merupakan motor penggerak sumber daya yang ada dalam rangka aktifitas dan rutinitas dari sebuah organisasi atau perusahaan. Sebagaimana diketahui sebuah organisasi atau perusahaan, didalamnya terdiri dari berbagai macam individu yang tergolong dari berbagai status yang mana status tersebut berupa pendidikan, jabatan dan golongan, pengalaman, jenis kelamin, status perkawinan, tingkat pengeluaran, serta tingkat usia dari masing - masing individu tersebut. (Beighton, Grahame, \& Bird, 2011), begitu juga tulisan Edi Yunus (Yunus, 2012) menyebutkan bahwa sumber daya manusia (SDM) adalah aset yang paling penting dalam sebuah perusahaan atau organisasi. Manajemen Sumber daya manusia merupakan hal terpenting yang dimiliki suatu organisasi, salah satu implikasinya adalah bahwa investasi terpenting yang mungkin dilakukan oleh suatu organisasi adalah di bidang sumber daya manusia (Wibowo, Wulan, \& Malik, 2019). Oleh karena itu agar sebuah organisasi dapat mencapai kinerja yang maksimal diperlukan perlakuan yang adil dan memuaskan pada sumber daya manusia yang bekerja pada organisasi tersebut.(Anggraeni, 2011).

Unjuk kerja seseorang merupakan perpaduan antara kemampuan, usaha dan kesempatan yang diperoleh(Syaharuddin, 2017). Kinerja akan sangat dipengaruhi oleh berbagai faktor baik dari karyawan maupun yang berasal dari organisasi (Nasfi, Iska, Nofrivul, \& Antoni, 2019). Kinerja pegawai sangat ditentukan oleh kemampuan atau kompetensinya. Sedangkan kinerja organisasi dipengaruhi oleh faktor gaya kepemimpinan yaitu seberapa baik pemimpin memberdayakan pekerjanya (Simangunsong, 2019). Hal ini pun diperkuat dengan pernyataan yang diungkapkan oleh (Umar, 2002) bahwa untuk menciptakan kinerja yang baik, maka perusahaan memerlukan suatu sistem atau teknik(Fauzi \& Locke, 2012). Teknik ini beroperasi pada peraturan atau standar namun melibatkan sumber daya manusianya. Kompetensi (Knowlege, Skill dan Ability) adalah suatu kapabilitas untuk merealisasikan suatu pekerjaan yang dilandasi atas keterampilan dan pengetahuan atau tingkat pendidikan serta didukung oleh perilaku kerja untuk mengupayakan pekerjaan tersebut (Wulandari \& Sriathi, 2012). kinerja dipengaruhi oleh tiga variabel yakni variabel individu, variabel organisasi dan variabel psikologi (Zees, 2012).

Kompetensi menggambarkan kualitas wawasan, keterampilan, perilaku, dan kemahiran untuk mengerjakan suatu pekerjaan atau peran tertentu secara tepat guna (Wulandari \& Sriathi, 2012). Pengetahuan melukiskan apa yang terdapat dalam kepala seseorang, mengetahui kesadaran atau pemahaman mengenai sesuatu, misalnya pemahaman mengenai pekerjaan. Kompetensi melukiskan kemampuan yang dapat diukur yang telah dikembangkan melalui praktik, pelatihan atau pengalaman (Sitindjak, 2016). Dengan demikian, kompetensi menerangkan keterampilan atau pengetahuan yang dibuktikan oleh pengalaman seseorang dalam suatu bidang tertentu sebagai unggulan bidangnya (Umar, 2002). Kompetensi sebagai keahlian seseorang untuk mewujudkan pada tingkat kerja yang maksimal di tempat kerja, termasuk bagaimana karyawan menerpakan keterampilan dan wawasan dalam suasana yang baru (Hartono, Indrawati, \& Hidayat, 2019).

Pemimpin adalah proses untuk memperdayakan orang lain untuk menafsirkan dan menyetujui dengan apa yang perlu diperbuat dalam menjalankan tanggung jawab secara efektif, serta memberikan pelayanan terhadap usaha individu untuk mencapai destinasi bersama (Djafri, 2017). Kepemimpinan yang dibutuhkan dewasa ini yaitu Knowledge, Skill dan Ability pimpinan yang mampu mengayomi karyawannya dengan menumbuhkan dan mengasah keberanian para karyawan dalam menjalankan tugasnya sehingga tercipta kinerja yang optimal (Wulandari \& Sriathi, 2012). 
Direktorat Industri Kecil Menengah berusaha untuk meningkatkan perekonomian di Kabupaten Pesisir Selatan dengan mengembangkan kompetensi yang ada di IKM Pesisir Selatan dengan memperhatikan sumber daya manusia berkualitas untuk dapat ikut berpacu dalam kompetisi global saat ini. Sebagai wujud keseriusannya dalam menangani masalah sumber daya manusia dengan meningkatkan kompetensi individu dan organisasi (Knowledge, Skill dan Ability). Hal ini menunjukkan bahwa kompetensi individu sangat diperlukan untuk membentuk kompetensi perusahaan itu sendiri (Kartika \& Sugiarto, 2014). Mencermati latar belakang masalah diatas, penulis tertarik untuk mendalaminya dan menganalisa lebih mendalam melalui suatu penelitian yang penulis tuangkan dalam judul penelitian : "Pengaruh Knowlege, Skill dan Ability Pimpinan Terhadap Kinerja IKM di Kabupaten Pesisir Selatan”.

\section{METODE PENELITIAN \\ Lokasi dan Waktu Penelitian}

Dalam penelitian ini penulis meneliti hal - hal yang berkaitan dengan Knowledge, Skill dan Ability pimpinan terhadap kinerja IKM pada Kabupaten Pesisir. Penelitian ini dilaksanakan mulai November 2018.

\section{Jenis Penelitian}

Jenis penelitian yang digunakan adalah kausatif. Penelitian kausatif merupakan tipe penelitian dengan karakteristik masalah berupa hubungan sebab akibat dengan dua variabel atau lebih. Tujuan dari penelitian ini yaitu untukmelihat pengaruh suatu variabel terhadap variable lain.Dalam hal ini menjelaskan dan menggambarkan serta memperlihatkan pengaruh Knowledge, Skill dan Ability pimpinan terhadap kinerja IKM di Kabupaten Pesisir Selatan.

\section{Jenis Data dan Sumber Data}

Jenis data yang digunakan sebagai berikut:

a. Data Kualitatif

Data yang diperoleh dalam bentuk informasi, baik secara lisan maupun tulisan yang antara lain berupa sejarah perusahaan dan penjelasan lain dan diperlukan dalam penulisan

b. Data Kuantitatif

Data yang diperoleh dalam bentuk angka yang dapat dihitung. Data ini diperoleh dari perhitungan kuisioner yang berhubungan dengan masalah yang dibahas dalam penelitian ini.

Adapun sumber data yang digunakan sebagai berikut:

a. Data Primer

Data yang diperoleh dengan mengumpulkan langsung dari objek penelitian, yaitu menyebarkan secara langsung kuisioner kepada responden terpilih.

b. Data Sekunder

Data yang berupa informasi tertulis maupun tidak tertulis yang diperoleh dari perusahaan, internet, majalah, koran, dan buku-buku yang berhubungan dengan penelitian ini.

\section{Populasi dan Sampel}

Populasi dalam penelitian ini adalah jumlah keseluruhan karyawan pada IKM Kabupaten Pesisir Selatan dengan jumlah karyawannya sebanyak 1656 orang. Dengan sampel sebanyak 100 orang diambil dari sejumlah unit Usaha yang bergerak dibidang Manufaktur seperti produksi kerajinan, makanan, tas,sepatu, kerupuk, garmen dan sebagainya di IKM Kabupaten Pesisir Selatan.

\section{Pengujian Instrumen Penelitian}

\section{a. Uji Validitas}

Validitas didefenisikan sebagai ukuran seberapa cermat suatu tes dilakukan, Alat ukur validitas, tidak sekedar mengungkapkan data dengan tetap, akan tetapi juga harus memberikan gambaran mengenai data tersebut. Sugiyono (2007) menyatakan bahwa syarat minimum untuk dianggap memenuhi syarat validitas adalah $r$ hitung $>0,30$. Jadi, apabila diperoleh $r$ hitung lebih besar dari 0,30 maka butir pernyataan dalam instrumen penelitian dinyatakan valid. 


\section{b. Uji Reliabilitas}

Uji reliabilitas adalah suatu uji yang menunjukkan sejauh mana pengukuran dapat memberikan hasil yang relatif tidak berbeda apabila dilakukan pengulangan pengukuran terhadap subjek yang sama. Uji ini hanya dapat dilakukan pada pertanyaan-pertanyaan yang valid saja. Untuk menentukan tingkat reliabilitas dari angket dilakukan dengan membandingkan nilai koefisien Alpha Cronbach, dimana instrumen memiliki tingkat reliabilitas tinggi jika nilai koefisien yang diperoleh $\geq 0,60$ (Ghozali, 2005).

\section{c. Uji Asumsi Klasik}

\section{1) Uji Normalitas}

Uji normalitas dilakukan dengan maksud memeriksa apakah data yang berasal dari populasi yang terdistribusi normal atau tidak. Menurut Santoso (2000) pedoman yang dipakai dalam uji normalitas ini adalah menggunakan uji Kolmogorov Smirnov yaitu:

- Jika nilai sig atau signifikansi atau nilai probabilitas (p) $<0,05$ ( taraf kepercayaan 95 $\%$ ), distribusi adalah tidak normal.

- Jika nilai sig atau signifikansi atau nilai probabilitas (p) > 0,05 (taraf kepercayaan 95 $\%$ ), distribusi adalah normal

\section{2) Uji Multikolinearitas}

Multikolineritas adalah keadaan dimana variabel-variabel independen dalam persamaan regresi mempunyai korelasi/hubungan yang erat satu sama lain. Menurut Gujarati (1999) Untuk mengetahui ada atau tidaknya masalah multikolineritas dilakukan dengan kriteria :

- Jika nilai VIF > 10, berarti terdapat korelasi yang tinggi sesama variabel bebas, maka terdapat multikolineritas pada tingkat kepercayaan $95 \%$

- Jika nilai VIF < 10, berarti tidak terdapat multikolineritas pada tingkat kepercayaan $95 \%$

\section{d. Regresi Linear Berganda}

Untuk mengetahui bagaimana pengaruh variable independen (bebas) terhadap variable dependent (terikat) dalam penelitian ini maka digunakan analisis Regresi Linear Berganda. Menentukan persamaan regresi linear berganda dengan rumus sebagai berikut:

$\mathrm{Y}=\mathrm{a}+\beta_{1} \mathrm{X}_{1}+\beta_{2} \mathrm{X}_{2}+\beta_{3} \mathrm{X}_{3}+\mathrm{e}$

\section{HASIL PENELITIAN}

\section{Uji Validitas}

\section{a. Hasil Uji Validitas Variabel Knowledge}

Variabel Knowledge pada penelitian ini di ukur dengan menggunakan 10 butir item pernyataan. Semua item pernyataan valid karena nilai koefisien korelasi ( $r$ hitung) lebih besar dari nilai $r$ kritis $(0,30)$, sehingga item pernyataan variabel Knowledge yang dianalisis adalah sebanyak 10 item pernyataan.

\section{b. Hasil Uji Validitas Variabel Skill}

Variabel Skill pada penelitian ini di ukur dengan menggunakan 10 butir item pernyataan. Semua item pernyataan valid karena nilai koefisien korelasi ( $\mathrm{r}$ hitung) lebih besar dari nilai $r$ kritis $(0,30)$, sehingga item pernyataan variabel Skill yang dianalisis adalah sebanyak 10 item pernyataan.

c. Hasil Uji Validitas Variabel Ability

Variabel Ability pada penelitian ini di ukur dengan menggunakan 10 butir item pernyataan. Semua item pernyataan valid karena nilai koefisien korelasi ( $r$ hitung) lebih besar dari nilai $r$ kritis $(0,30)$, sehingga item pernyataan variabel Ability yang dianalisis adalah sebanyak 10 item pernyataan.

\section{d. Hasil Uji Validitas Variabel Kinerja Pimpinan}

Variabel Kinerja Pimpinan pada penelitian ini di ukur dengan menggunakan 15 butir item pernyataan. Semua item pernyataan valid karena nilai koefisien korelasi ( $r$ hitung) lebih besar dari nilai $r$ kritis $(0,30)$, sehingga item pernyataan variabel Kinerja Pimpinan yang dianalisis adalah sebanyak 15 item pernyataan. 


\section{Uji Reliabilitas}

Hasil analisis reliabilitas dari masing-masing variabel yaitu Variabel Knowledge (X1), Skill (X2), Ability (X3) dan Kinerja Pimpinan (Y), memiliki angka alpha cronbach lebih besar dari 0,6 . Hal ini menandakan bahwa semua variabel) memiliki kuisioner yang handal atau reliabel.

\section{Uji Asumsi Klasik}

\section{a. Uji Normalitas}

Hasil uji normalitas diketahui bahwa nilai Asym.Sig (2-tailed) untuk variabel Knowledge $\left(\mathrm{X}_{1}\right)$ sebesar 0,114, variabel Skill $\left(\mathrm{X}_{2}\right)$ sebesar 0,104, Variabel Ability (X3) sebesar 0,106 dan variabel Kinerja (Y) sebesar 0,099, Jadi, dapat disimpulkan bahwa nilai Asym.Sig (2-tailed) dari semua variabel penelitian nilainya lebih besar dari tingkat signifikan yang digunakan pada penelitian ini $(\alpha=0,05)$. Dengan demikian dapat disimpulkan bahwa semua variabel penelitian berdistribusi normal, berarti analisis regresi dapat dilaksanakan karena data telah berdistribusi normal.

\section{b. Uji Multikolinearitas}

Hasil uji multikolineritas diketahui bahwa nilai tolerance dari Collinearity Statistics mendekati 1 (satu) dan nilai VIF (Variance Inflation Factor) untuk semua variabel bebas di bawah 5 (lima). Hal ini menunjukkan bahwa tidak terdapat kasus multikolinearitas antara sesama variabel bebas. Oleh karena itu dapat disimpulkan bahwa data hasil penelitian ini dapat dilakukan pengolahan data dengan regresi linear berganda karena tidak terdapat kasus multikolinearitas antara sesama variabel bebas.

\section{c. Uji Heterokedastisitas}

Uji heterokedastisitas adalah bertujuan untuk menguji apakah dalam sebuah model regresi terjadi ketidak samaan varian residual dari satu pengamatan ke pengamatan yang lain. Jika varian dari rasidualnya tetap, maka tidak ada heterokedastisitaas. Model regresi yang baik terbebas dari herokedastisitas. Pengujian terhadap heterokedastisitas dilakukan dengan melihat ada tidaknya pola pola tertentu pada grafik scatterplot. Dari hasil grafik yang diolah melakukan analisa regresi berganda didapati titik menyebar diatas dan dibawah angka 0 pada sumbu Y, maka dari hasil tersebut dapat disimpulkan tidak ada heterokedastisitas.

\section{Hasil Analisa Regresi Linier Berganda}

Hasil analisis regresi Linier berganda melihat Pengaruh Knowledge $\left(\mathrm{X}_{1}\right)$, Skill $\left(\mathrm{X}_{2}\right)$ dan Ability $\left(\mathrm{X}_{3}\right)$ terhadap Kinerja $(\mathrm{Y})$. Dari hasil pengolahan data didapati bahwa nilai koefisien regresi dari masing-masing variabel penelitian adalah variabel Knowledge $\left(\mathrm{X}_{1}\right)$ adalah 0,251, Skill $\left(\mathrm{X}_{2}\right)$ adalah 0,016 dan Ability adalah 0,123, dengan nilai konstanta sebesar 43,688. Kemudian, nilai koefisien regresi masing-masing variabel di atas dapat disubstitusikan ke dalam persamaan regresi berganda sebagai berikut:

$\mathrm{Y}=\mathrm{a}+\mathrm{b}_{1} \mathrm{X}_{1}+\mathrm{b}_{2} \mathrm{X}_{2}+\mathrm{b}_{3} \mathrm{X}_{3}+\mathrm{e}$

$Y=43,688+0,251 X_{1}+0,016 X_{2}+0,123 X_{3}$

Nilai koefisien yang disubsitusikan ke dalam persamaan di atas dapat diartikan sebagai berikut:

a. Nilai konstanta sebesar 43,688 , hal ini menunjukkan bahwa sebelum dipengaruhi oleh Knowledge $\left(\mathrm{X}_{1}\right)$, Skill $\left(\mathrm{X}_{2}\right)$ dan Ability $\left(\mathrm{X}_{3}\right)$, maka nilai Kinerja sebesar 56,312.

b. Koefisien regresi dari Knowledge $\left(\mathrm{X}_{1}\right)$ sebesar 0,251 yang bertanda positif, menunjukkan bahwa dengan peningkatan dari Knowledge $\left(\mathrm{X}_{1}\right)$ dalam setiap satuannya akan meningkatkan Kinerja sebesar 0,251 dalam setiap satuan dengan asumsi variabel lain tidak mengalami perubahan (catteries paribus).

c. Koefisien regresi dari Skill $\left(\mathrm{X}_{2}\right)$ sebesar 0,016 yang bertanda positif, menunjukkan bahwa dengan peningkatan dari Skill $\left(\mathrm{X}_{2}\right)$ dalam setiap satuannya akan meningkatkan Kinerja sebesar 0,016 dalam setiap satuan dengan asumsi variabel lain tidak mengalami perubahan (catteries paribus).

d. Koefisien regresi dari Ability $\left(\mathrm{X}_{3}\right)$ sebesar 0,123 yang bertanda positif, menunjukkan bahwa dengan peningkatan dari Ability $\left(\mathrm{X}_{3}\right)$ dalam setiap satuannya akan meningkatkan 
Kinerja sebesar 0,123 dalam setiap satuan dengan asumsi variabel lain tidak mengalami perubahan (catteries paribus).

\section{Pengujian Hipotesis dan Pembahasan}

Hipotesis merupakan suatu kesimpulan yang sifatnya sementara dan masih dibuktikan kebenarannya. Sebagaimana yang telah dikemukakan sebelumnya, penelitian ini mengembangkan Lima hipotesis yang perlu dilakukan pengujian yaitu:

\section{H1 : Knowledge berpengaruh signifikan terhadap Kinerja Pimpinan IKM Kabupaten Pesisir Selatan}

Koefisien regresi dari Knowledge $\left(\mathrm{X}_{1}\right)$ sebesar 0,251 yang bertanda positif, Nilai signifikansi dari variabel Knowledge $\left(\mathrm{X}_{1}\right)$ adalah sebesar 0,031. Jika nilai signifikansi dibandingkan dengan tingkat signifikan yang digunakan dalam penelitian ini $(\alpha=0,05)$ maka terbukti bahwa nilai signifikansi lebih kecil dari tingkat signifikan yang digunakan $(0,031<0,05)$. Hal ini berarti terdapat pengaruh yang signifikan dan positif Knowledge $\left(\mathrm{X}_{1}\right)$ terhadap Kinerja $(\mathrm{Y})$. Dengan demikian hipotesis yang diajukan dapat diterima pada tingkat kepercayaan 95\%.

2. H2 : Skill berpengaruh signifikan terhadap Kinerja Pimpinan IKM Kabupaten Pesisir Selatan

Koefisien regresi dari Skill $\left(\mathrm{X}_{2}\right)$ sebesar 0,016 yang bertanda positif, Nilai signifikansi dari variabel Skill $\left(\mathrm{X}_{2}\right)$ adalah sebesar 0,028. Jika nilai signifikansi dibandingkan dengan tingkat signifikan yang digunakan dalam penelitian ini $(\alpha=0,05)$ maka terbukti bahwa nilai signifikansi lebih kecil dari tingkat signifikan yang digunakan $(0,028<0,05)$. Hal ini berarti terdapat pengaruh yang signifikan dan positif Skill $\left(\mathrm{X}_{2}\right)$ terhadap Kinerja (Y). Dengan demikian hipotesis yang diajukan dapat diterima pada tingkat kepercayaan 95\%.

3. H3 : Ability berpengaruh signifikan terhadap Kinerja Pimpinan IKM Kabupaten Pesisir

\section{Selatan}

Koefisien regresi dari Ability $\left(\mathrm{X}_{3}\right)$ sebesar 0,123 yang bertanda positif, Nilai signifikansi dari variabel Ability $\left(\mathrm{X}_{3}\right)$ adalah sebesar 0,046. Jika nilai signifikansi dibandingkan dengan tingkat signifikan yang digunakan dalam penelitian ini $(\alpha=0,05)$ maka terbukti bahwa nilai signifikansi lebih kecil dari tingkat signifikan yang digunakan $(0,046<0,05)$. Hal ini berarti terdapat pengaruh yang signifikan dan positif Ability $\left(\mathrm{X}_{3}\right)$ terhadap Kinerja (Y). Dengan demikian hipotesis yang diajukan dapat diterima pada tingkat kepercayaan 95\%.

4. H4 : Knowledge, Skill, Ability berpengaruh signifikan terhadap Kinerja Pimpinan IKM Kabupaten Pesisir Selatan

\section{a. Uji F}

Dari hasil pengujian $\mathrm{F}$ diketahui bahwa tingkat signifikan sebesar 0,041 yang bertanda positif, maka Jika nilai signifikansi (sig) atau nilai probabilitas (probAbility) lebih kecil dari tingkat signifikan yang digunakan $(\alpha=0,05)$ berarti model regresi yang dihasilkan adalah prediktor yang valid, maka terbukti bahwa nilai $\mathrm{F}$ lebih kecil dari tingkat signifikan yang digunakan $(0,041<0,05)$. Hal ini berarti terdapat pengaruh yang signifikan dan positif Knowledge $\left(\mathrm{X}_{1}\right)$, Skill $\left(\mathrm{X}_{2}\right)$ dan Ability $\left(\mathrm{X}_{3}\right)$ terhadap Kinerja ( $\left.\mathrm{Y}\right)$. Dengan demikian hipotesis yang diajukan dapat diterima.

\section{b. Uji t}

Dari hasil pengujian diketahui Nilai signifikansi dari variabel Knowledge $\left(\mathrm{X}_{1}\right)$ adalah sebesar 0,031, Nilai signifikansi dari variabel Skill $\left(\mathrm{X}_{2}\right)$ adalah sebesar 0,028 dan Nilai signifikansi dari variabel Ability $\left(\mathrm{X}_{3}\right)$ adalah sebesar 0,046, maka terbukti Jika nilai signifikansi (sig) atau nilai probabilitas (probAbility) lebih kecil dari tingkat signifikan yang digunakan $(\alpha=0,05)$, maka dapat disimpulkan bahwa terdapat pengaruh yang signifikan dari variabel Knowledge $\left(\mathrm{X}_{1}\right)$, Skill $\left(\mathrm{X}_{2}\right)$ dan Ability $\left(\mathrm{X}_{3}\right)$ terhadap Kinerja. 


\section{KESIMPULAN DAN SARAN}

1. Knowledge berpengaruh signifikan terhadap Kinerja Pimpinan IKM Kabupaten Pesisir Selatan. Nilai signifikansi dari variabel Knowledge $\left(\mathrm{X}_{1}\right)$ adalah sebesar 0,031. Tingkat signifikan yang digunakan $(0,031<0,05)$, hal ini berarti terdapat pengaruh yang signifikan dan positif Knowledge $\left(\mathrm{X}_{1}\right)$ terhadap Kinerja $(\mathrm{Y})$.

2. Skill berpengaruh signifikan terhadap Kinerja Pimpinan IKM Kabupaten Pesisir Selatan. Nilai signifikansi dari variabel Skill $\left(\mathrm{X}_{2}\right)$ adalah sebesar 0,028. Tingkat signifikan yang digunakan $(0,028<0,05)$. Hal ini berarti terdapat pengaruh yang signifikan dan positif Skill $\left(\mathrm{X}_{2}\right)$ terhadap Kinerja (Y).

3. Ability berpengaruh signifikan terhadap Kinerja Pimpinan IKM Kabupaten Pesisir Selatan. Nilai signifikansi dari variabel Ability $\left(\mathrm{X}_{3}\right)$ adalah sebesar 0,046 . Tingkat signifikan yang digunakan $(0,046<0,05)$. Hal ini berarti terdapat pengaruh yang signifikan dan positif Ability $\left(\mathrm{X}_{3}\right)$ terhadap Kinerja $(\mathrm{Y})$.

4. Knowledge, Skill, Ability berpengaruh signifikan terhadap Kinerja Pimpinan IKM Kabupaten Pesisir Selatan

5. Uji F

Hasil pengujian $\mathrm{F}$ diketahui bahwa tingkat signifikan sebesar 0,041 yang bertanda positif, tingkat signifikan yang digunakan $(0,041<0,05)$. Hal ini berarti terdapat pengaruh yang signifikan dan positif Knowledge $\left(\mathrm{X}_{1}\right)$, Skill $\left(\mathrm{X}_{2}\right)$ dan Ability $\left(\mathrm{X}_{3}\right)$ terhadap Kinerja ( $\left.\mathrm{Y}\right)$.

6. Uji t

Dari hasil pengujian diketahui Nilai signifikansi dari variabel Knowledge $\left(\mathrm{X}_{1}\right)$ adalah sebesar 0,031, Nilai signifikansi dari variabel Skill $\left(\mathrm{X}_{2}\right)$ adalah sebesar 0,028 dan Nilai signifikansi dari variabel $A$ bility $\left(\mathrm{X}_{3}\right)$ adalah sebesar 0,046, maka terbukti Jika nilai signifikansi (sig) atau nilai probabilitas (probAbility) lebih kecil dari tingkat signifikan yang digunakan $(\alpha=0,05)$ maka dapat disimpulkan bahwa terdapat pengaruh yang signifikan dari variabel Knowledge $\left(\mathrm{X}_{1}\right)$, Skill $\left(\mathrm{X}_{2}\right)$ dan Ability $\left(\mathrm{X}_{3}\right)$ terhadap Kinerja.

\section{DAFTAR KEPUSTAKAAN}

Akramiah, N., \& Fibriyani, V. 2018. Pengaruh Orientasi Wirausaha dan Orientasi Pasar terhadap Kinerja Usaha Mikro Kota Pasuruan. Jurnal EMA, 3 (1).

Amin, M., \& Wibowo, N. M. 2019. Pengaruh Kepemimpinan Transformasional, Motivasi Kerja dan Kualitas SDM terhadap Kinerja Personel Satuan Lalu Lintas Polres Pamekasan. MAP (Jurnal Manajemen Dan Administrasi Publik), 2 (04), 516-530.

Anggraeni, N. 2011. Pengaruh Kemampuan dan Motivasi Terhadap Kinerja Pegawai Pada Sekolah Tinggi Seni Indonesia (STSI) Bandung. Jurnal Penelitian Pendidikan, 12 (2), 54-74.

Ardiana, I., Brahmayanti, I. A., \& Subaedi, S. 2010. Kompetensi SDM UKM dan pengaruhnya terhadap kinerja UKM di Surabaya. Jurnal Manajemen Dan Kewirausahaan, 12 (1), 42-55.

Beighton, P. H., Grahame, R., \& Bird, H. 2011. Hypermobility of Joints. Springer Science \& Business Media.

Deikme, P. 2013. Motivasi Kerja dan Budaya Organisasi Pengaruhnya tzerhadap Kinerja Pegawai Bagian Keuangan Sekda Kabupaten Mimika Provinsi Papua. Jurnal EMBA: Jurnal Riset Ekonomi, Manajemen, Bisnis Dan Akuntansi, 1 (3).

Djafri, N. 2017. Manajemen Kepemimpinan Kepala Sekolah:(Pengetahuan Manajemen, Efektivitas, Kemandirian Keunggulan Bersaing dan Kecerdasan Emosi). Deepublish.

Fauzi, F., \& Locke, S. 2012. Board Structure, Ownership Structure and Firm Performance: A study of New Zealand Listed-Firms.

Gibson, James L, Ivancevich, John M., Donelly, James H. Jr. 1994. Organizations: Behavior, Structure, Processes. 
Hartono, S. B., Indrawati, M., \& Hidayat, H. 2019. Kinerja Pegawai Kantor Pertahanan Kabupaten Tuban Ditinjau dari Kompetensi, Keterampilan dan Kepemiimpinan. Jurnal Mitra Manajemen, 3 (5), 536-547.

Jahja, Y. (2011). Psikologi Perkembangan. Kencana.

Karmilati, K., \& Purbasari, R. R. N. 2012. Pengukuran Kinerja Usaha Kecil Menengah Menurut Faktor Kompetensi Sumbar Daya Manusia. Jurnal Bisnis Dan Akuntansi, 14 (3), 227238.

Kartika, L. N., \& Sugiarto, A. 2014. Pengaruh Tingkat Kompetensi terhadap Kinerja Pegawai Administrasi Perkantoran. Jurnal Ekonomi Dan Bisnis, 17 (1), 73-90.

Direktorat Jenderal Pendidikan dan Kebudayaan. 2012. Seminar Nasional Cakrawala Pembelajaran Berkualitas di Indonesia.

Nasfi, N., Iska, S., Nofrivul, N., \& Antoni, A. 2019. Financial Sustainability in the Assessment of The Financial Performance of West Sumatra Sharia Financing Bank (BPRS). MENARA EKONOMI, 5 (1).

Nasution, H. F. 2015. Urgensi Kemampuan Matematis dalam Menganalisis Teori-Teori Ekonomi. Al-Masharif: Jurnal Ilmu Ekonomi Dan Keislaman, 3 (2), 100-113.

Pratiwi, A., \& Darmastuti, I. 2014. Pengaruh Motivasi dan Disiplin Kerja Terhadap Kinerja Pegawai (Studi Pada PT. Telekomunikasi Indonesia, Tbk Wilayah Telkom Pekalongan). Fakultas Ekonomika dan Bisnis.

Prawatya, D. A., \& Rahardjo, S. T. 2012. Pengaruh Disiplin Kerja dan Budaya Organisasi terhadap Kinerja Karyawan Pabrik Minyak Kayu Putih (PMKP) di Krai Purwodadi. Fakultas Ekonomika dan Bisnis.

Robbins, S. P., \& Judge, T. 2009. Organizacijsko Ponašanje. Mate.

Satria Yudha, C. A., \& Ruhana, I. 2013. Pengaruh Motivasi Kerja Dan Kemampuan Kerja terhadap Kinerja Karyawan (Studi pada Karyawan Perusahaan Daerah Air Minum (PDAM) Kota Malang). Jurnal Administrasi Bisnis, 2(2), 56-75.

Simangunsong, R. E. 2019. Pengaruh Gaya Kepemimpinan dan Budaya Organisasi terhadap Kinerja Pegawai pada Dinas Perindustrian dan Perdagangan Provinsi Sumatera Utara.

Sitindjak, V. 2016. Pengaruh Komponen Pengelolaan Pendidikan dan Pelatihan terhadap Kompetensi Alumni Pendididkan dan Pelatihan Kepemimpinan Tingkat III di Lingkungan Pemerintah Provinsi Jawa Barat. Jurnal Inspirasi, 7 (3), 115-123.

Sudiarta, I. P. L. E., Kirya, I. K., \& Cipta, W. 2014. Analisis Faktor-Faktor yang Mempengaruhi Kinerja Usaha Mikro Kecil dan Menengah (UMKM) di Kabupaten Bangli. Jurnal Jurusan Manajemen, 2 (1).

Suhartini, Y. (2014). Pengaruh Faktor-Faktor Kompetensi Sumber Daya Manusia Terhadap Kinerja Karyawan (Studi Kasus pada Sales Supervisor Pertokoan Sepanjang Malioboro Yogyakarta). Online. Diunduh Tgl, 14.

Suwati, Y. (2013). Pengaruh Kompensasi dan Motivasi Kerja terhadap Kinerja Karyawan pada PT. Tunas Hijau Samarinda. Jurnal Ilmu Administrasi Bisnis, 1 (1), 41-55.

Syaharuddin, Y. 2017. Pengaruh Pengembangan Sumber Daya Manusia terhadap Kinerja Pejabat Struktural di Lingkungan Unviersitas Mulawarman. Jurnal Ekonomika: Manajemen, Akuntansi, Dan Perbankan Syari'ah, 4 (1), 12-19.

Umar, H. 2002. Metode Riset Bisnis: Panduan Mahasiswa untuk Melaksanakan Riset Dilengkapi Contoh Proposal dan Hasil Riset Bidang Manajemen dan Akuntansi. Gramedia Pustaka Utama. 
Wibowo, Y. A., Wulan, H. S., \& Malik, D. 2019. Influence of Ability, Personality and Motivation on Teacher Performance (Studi Kasus Pada Guru SD Negeri Kemiri Kecamatan Gubug Purwodadi). Journal of Management, 5 (5).

Wulandari, T. R., \& Sriathi, A. A. A. 2012. Pengaruh Kompetensi Dan Persepsi Kepemimpinan Terhadap Kinerja Karyawan Pada PT. Bank BPD Bali Cabang Utama Denpasar. EJurnal Manajemen, 3 (3).

Yunus, E. 2012. The Influence of Employee Participation on Jamsostek and Pension Fund to Productivity in PT Cement Gresik (Persero). Jurnal Aplikasi Manajemen, 10(2), 303309.

Yustiana, T. 2018. Pemanfaatan Bahan Alam Biji-bijian untuk Meningkatkan Keterampilan Membuat Mozaik dalam Tema Kegiatanku di Kelas 1 Sekolah Dasar. Jurnal Penelitian Pendidikan Guru Sekolah Dasar, 6 (2).

Zees, R. F. 2012. Analisis Faktor Budaya Organisasi Yang Berhubungan Dengan Perilaku Caring Perawat Pelaksana Di Ruang Rawat Inap RSUD. Prof. Dr. H. Aloei Saboe Kota Gorontalo. Jurnal Health and Sport, 5 (01). 